\title{
DEVELOPING COMMUNICATION AND CRITICAL THINKING THROUGH CREATIVE WRITING IN ENGLISH AND FRENCH LANGUAGE: ANALYSIS OF CLASSR0OM MANAGEMENT STRATEGIES
}

\begin{abstract}
Developing critical thinking skills in university students has become a primary goal in higher education. This study investigated the efficacy of the classroom management strategies for developing critical thinking skills in undergraduate students in the class. The four strategies were incorporated into the 54-hour English program: 1) "Reading circles" strategy; 2) Socratic-questions-based discussions; 3) Group presentations; 4) Writing assignments (abstracts, essays, reports). Students took a multiple-choice pretest and posttest (Cambridge Thinking Skills Assessment Test) and answered a Satisfaction Questionnaire. The study produced several findings: 1) students' overall critical thinking skills made significant improvement by the end of the course; 2) the students showed better academic achievements in English at the end-term exam; 3) the students were more interested and motivated in thinking-based learning; 4) the students found the guided in-class activities ("reading circles"; Socratic-questions-based discussions) more effective than other student-directed activities (group presentations; writing assignments) in developing critical thinking.
\end{abstract}

Keywords: classroom management strategies, classroom management principles, critical thinking skills, thinking-based learning, EFL teaching

\section{Introduction}

In the global world, critical thinking skills (CTS) are believed to be crucial in everyday life, in different academic and professional domains. People who demonstrate high CTS can function well in society, perform better in the workplace or in class, and make better personal or business decisions. Responding to the need, higher education considers the development of CTS in undergraduate students a primary goal. Scholars Braun [1], Halpern [2], Klaczynski [3] state that the development of critical thinking skills in students is very important. Using them, students "know how to learn and how to think clearly" [2] and "make purposeful judgments about what to believe or what to do." [4] Moreover, with good critical thinking ability, university graduates can be better prepared to exercise their rights and responsibilities in a global or local community.
Besides, the creative writing also communicates the author's abstract, creative mind, and interprets how organized he/ she knows to be when writing a context.

In the journal XLinguae during 2017, several articles were published which were concerned with writing on a university level. See the articles of Dolzhikova, A., Kurilenko, V., Biryukova, Y., Rumyantseva, N., Makarova, M., Kulikova, E. [5], Karamalak, O., Pesina, S. [6], Fenclova, M., Horova, H. [7], Klimova, K. [8], Ahmadi, A., Meihami, H. [9], Tareva, E. G., Schepilova, A. V., Tarev, B. V. [10], Palashevskaya, I. V., Leontiev, V. V., Kurchenkova, E. A., Stepanova, E. D., Bulanov [11], Kralova, Z., Petrova, G. [12], Lah, M. [13].

The importance of this belief has encouraged teachers to reconsider the EFL programme at the Omsk State Agricultural University (OSAU) infusing critical-thinking-based approach to EFL teaching and in Constantine the Philosopher University

\footnotetext{
* ${ }^{1}$ Irina V. Kulamikhina, ${ }^{2}$ Jana Birova, ${ }^{3}$ Aleksei Yu. Alipichev, ${ }^{4}$ Dinara G. Vasbieva, ${ }^{4}$ Olga A. Kalugina ${ }^{1}$ Foreign Languages Department, Omsk State Agrarian University named after P.A. Stolypin, Omsk, Russia ${ }^{2}$ Faculty of Arts, Ss. Cyril and Methodius University in Trnava, Slovakia,

${ }^{3}$ Foreign Languages Department, Russian Timiryazev State Agrarian University, Moscow, Russia

${ }^{4}$ Foreign Languages Department, Financial University under the Government of the Russian Federation, Moscow, Russia

E-mail: jbirova@yahoo.fr
} 
CRITICAL THINKING MODEL

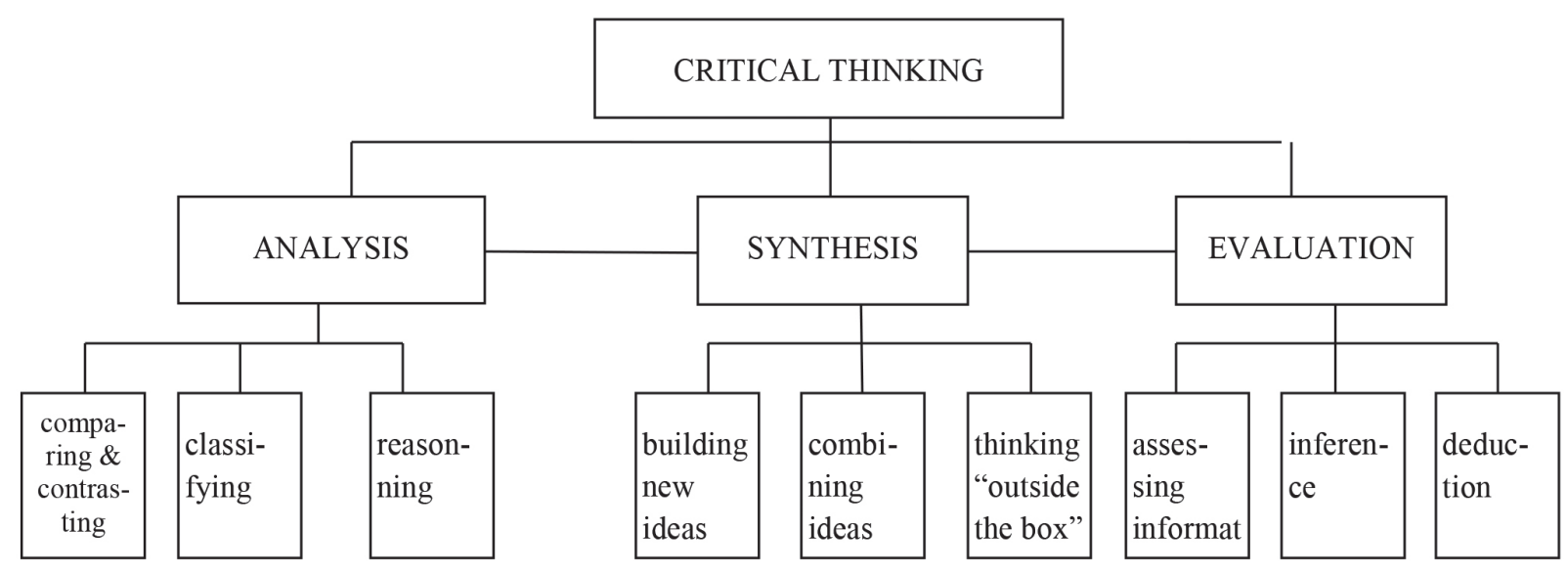

Figure 1 Critical thinking model

in Nitra to FFL (French foreign language) teaching. Teachers and professors at OSAU have to state that the majority of $1^{\text {st }}$ year agricultural students lack key life skills such as critical thinking, teamwork, and self-direction which are most in need for successful academic studies at the University. The causes for such a problem are complex. First of all, a big number of students come from different social backgrounds and communities like small villages, small towns with poor educational opportunities. Most students' previous learning experience in the secondary school was mainly reproduction-oriented [14]. They were seldom given the chances to find out, explain, or evaluate the "knowledge" instructed in the classroom. They were more engaged in work as a class or individually, so they do not have a disposition towards cooperation and collaboration in the classroom. In general, these students are not quite motivated, inquisitive, or confident. To add more, they are immature in critical thinking.

Therefore, EFL teachers and professors at OSAU face the problem of creating a special motivation-learning environment in order to reverse students' learning habits and set of minds towards critical thinking in an EFL classroom. This study aims at the effective classroom management strategies for developing critical thinking skills in students in EFL class.

\section{Theoretical questions}

This study focuses on the following research questions: 1) What is critical thinking? 2) How is this skill revealed and how can it be measured in students? 3) What are appropriate pedagogical approaches and classroom management principles for teaching critical thinking in the EFL class? and 4) What are the specific classroom management strategies; which are most beneficial in helping students develop critical thinking?

\subsection{Theoretical framework}

There are many different theoretical frameworks (Figure 1) about what critical thinking might be. [1], [15], [16], [4], [2], [17], [18]. For our purposes, we have selected two frameworks on types of thinking which we believe supplement one another and could be used in a practical educational application in our research. The first one is Bloom's taxonomy of six educational objectives [18] - knowledge, comprehension, application, analysis, synthesis, and evaluation. Knowledge and comprehension refer to so-called "lower order thinking" whereas the final four objectives in the taxonomy define "higher order thinking." The movement from the first two goals (knowledge and comprehension) to the final four goals (application, analysis, synthesis, and evaluation) represents a change from lower order thinking to higher order thinking.

The second classification of critical thinking skills belongs to Robert Ennis. He recognizes the thinking abilities which are to do with the clarification and analysis of arguments, and the assessment of their validity. They also include abilities in judging the credibility of sources, deduction, and induction, evaluating value judgments, uncovering unstated assumptions, and suppositional thinking [15], [16]. Sharing Swartz's idea about the compatibility of different approaches to types of thinking [19], we found a way of combining the above two frameworks. Thus, based on Bloom's taxonomy which we expand with Ennis' more differentiated types of thinking, we identify the three main critical thinking categories - analysis, synthesis, evaluation - that fall into subcategories. For example, analytical skills are represented by comparing and contrasting skills, classifying skills, and reasoning skills. Synthesizing skills fall into the building and combining ideas skills, thinking "outside the box" skills. Evaluation skills include assessing information, inference, and deductive skills. All these thinking skills are at the core of critical thinking. In relation to the education domain, these types of thinking skills 
are considered both as additional educational goals and learning outcomes in a critical thinking-based EFL curriculum.

For assessing the progress of student thinking skills, we used two approaches: a testing approach (Swartz and McGuinness) and a curriculum approach. With the first approach, students' thinking skills were assessed with a multiple-choice test (Cambridge Thinking Skills Assessment Test). With the second one, thinking skills were assessed as they were manifested by students in a specific learning context in terms of the quality of a student-written work or a performance of some kind (e.g., a group presentation, a guided discussion, etc.). The second tradition involved the use of criterion-related schemes developed for teacher-, peer- or self-assessment (Appendixes 1, 2, 3).

The next important issue is the classroom management principles for teaching thinking in the EFL classroom. As EFL teachers, we used an approach of infusing the teaching of thinking into the content instruction [19], [20]. With this approach, the thinking skills and the curriculum content were taught simultaneously. Designing an EFL programme, we followed the four principles of thinking-based language learning and teaching:

1. Making meaning in language learning is very important. The more students are stimulated intellectually and emotionally, the more knowledge and skills they will develop [21]. One of the ways to engage students in meaningful language learning is by organizing thought-provoking content including topics preparing students for social, academic and professional contexts.

2. Active learning helps students to be more involved in the learning process. With this model of instruction, students are more responsible for their learning outcomes. Active learning engages students in two aspects - doing things and thinking about the things they are doing [22].

3. Cooperative learning gives students more opportunities for meaningful communication. Students learning cooperatively can capitalize on one another's resources and skills (asking one another for information, evaluating one another's ideas, monitoring one another's work, etc.) [23] compare also with [24], [25], [26], [27], [28], [29], [30], [31]. Besides, students in cooperative learning settings compared to those in individualistic or competitive learning settings; achieve more, reason better, gain higher self-esteem, like their classmates and the learning tasks more and have more perceived social support-[32].

4. Using thinking organizers in the classroom is important to teach thinking successfully. Students can be provided with challenging stimulus materials or strategies, which prompt them to think in deeper ways and engage them in analysis, synthesis, or evaluation. Maps and graphics are good examples of thinking organizers [19], [20]. Other thinking organizers are a PMI (Plus, Minus, and Interesting) strategy [33] and guiding questions. These strategies serve as motivators and organizers of higher-order thinking.

\section{Research}

\subsection{Research questions and objectives}

Research questions:

How will university students in Russia and in Slovakia improve their critical thinking?

Will students in Russia perform and score better than students in Slovakia?

What are the most suitable techniques for developing critical thinking skills in students in EFL and/or FFL classes?

The research objectives of this study are the following:

- to identify the improvement of the critical thinking of the examined group of students

- to identify the score of Russian and Slovak students in order to compare

- to find out some suitable techniques for critical thinking development,

\subsection{Research methods}

In order to map the students' improvement, direct observation, pedagogical diagnostics and the method of pretest and posttest were used.

\subsection{Research samples: participants, settings}

Omsk State Agricultural University students (Russia) 75 English-speaking students

Constantine the Philosopher University students (Slovakia) 12 French-speaking students

\subsection{Research procedure}

The present study was conducted in the second term of the academic year of 2016-2017 at the Omsk State Agricultural University (OSAU). Participants in this study were 60 first-year students (4 academic groups) who got into Bachelor's degree programmes in Agronomy and Land Management. At OSAU, EFL teachers deal with a complex problem when teaching a foreign language: the prevailing low language proficiency in students together with a low disposition towards learning, in general. With the selected participants, we had the following situation. The students within each group demonstrated different levels of language skills with prevailing low proficiency. This situation was revealed in the language pretest at the start of the academic year. Both teachers and students were anxious about EFL end-term outcomes. Therefore, during the $1^{\text {st }}$ semester, the teachers put a lot of effort into developing the elementary language 
skills of those students who lacked them at all so that they could pass the end-term exam. The results of this exam showed little progress in students with different language skills. In our opinion, the reason was the lack of good thinking skills in students or a low disposition towards thinking in class. We strongly believed that by developing good critical thinking skills, our undergraduates would manage to improve language skills significantly together with their social abilities. There is a correlation between thinking abilities and high academic performances [34], [35].

To engage students into higher-order thinking, we chose a few strategies to incorporate into the 54-hour EFL curriculum of the second semester: 1) "Reading circles" strategy; 2) Socraticquestions-based discussions; 3) Group presentations; 4) Writing assignments (abstracts, essays, reports).

Now we turn to the perspectives of each strategy in relation to critical thinking.

1. Why "Reading circles"? The mental process of reading requires critical thinking skills. Reading is a complex process that makes readers recall, retrieve and reflect on their prior experiences or memories to construct meanings of the text. While they are doing so, they need to demonstrate the following capacities: to differentiate facts from opinions; to understand the implied meanings; to find out the relationship between the events, actions or details; to perceive multiple points of views; and to make reasoning and judgments. Thus, reading activities involve explanation, analysis, synthesis, argumentation, evaluation, inference, and logical reasoning, which sum up critical thinking competency.

A reading circle strategy groups students together in a circle to collaboratively discuss and analyze what they have read reinforcing listening, speaking, reading, and writing skills [36]. Reading circles can be especially useful in a class with students of different language proficiency.

Now we are going to describe how we implemented "reading circles" strategy in the EFL classroom.

Step 1: the EFL teachers carefully selected texts on social, academic and professional topics chosen for their thoughtprovoking qualities.

Step 2: Based on the text, the teachers selected and described reading-circle roles for students. Four specific roles were identified as essential: 1. Word Organizer (identifies and systemizes topical words and words with special meaning in the text); 2. Illustrator (responds graphically to the text); 3. Summarizer (recaps the key points, main highlights, and a general idea of the text); 4 . Questioner (analyzes the text through contextual questioning). Besides, there were other optional roles which were implemented according to the classroom needs: 1. Planner (identifies important parts of the text and makes a plan of it); 2. Connector (connects the ideas, events of the text and finds out the relationship between them); 3. Language Expert (analyses the language of the text: grammar rules and vocabulary usage); 4. Classifier (finds out and classifies the arguments in the text); 5. Analyst (compares and contrasts information in the text, sequences the events, etc.).

Step 3: The teachers put the students in groups of 4-8, and each student in the group received a written text and a role-card with the description of the task and a thinking organizer to ensure their efficacy in a particular thinking activity in the specific role. To formulate a role task, the teachers used specific thinking vocabulary: for example "explain why," "compare and contrast," "analyze," "classify," "make inferences," etc.

Students were assigned 40-45 minutes for doing thoughtprovoking reading activities. The rest of the 45-50 minutes of the class were fixed for sharing results and a question-guided discussion within each group.

Step 4: The teachers used various types of assessment of learning outcomes, such as:

1. Self-assessment. Students gave feedback on what they had done in the specific role, what difficulties they had experienced, what they liked or not in the activity, what new information or skill they had learned or practiced. (Appendix 3)

2. Peer-assessment. Based on the given checklist, students assessed the performance of other group members. (Appendix 2)

3. Observation. Teachers circulated through the classroom during reading-circle activities correcting students' mistakes, giving prompts, encouraging students to express their thoughts and ideas. Ongoing observation helped teachers in assessing student progress and identifying their difficulties.

3. Student Artifacts. Teachers collected and checked role sheets completed by students to assess their language and thinking progress.

2. Socratic-questions-based discussions. Since Socratic questioning is at the heart of critical thinking, it stimulates students' thinking process and engages them in the analytic discussion, which leads to independent learning and thinking. As a teaching strategy, Socratic-question-based discussions could be a part of a teaching-learning process when working on a writing assignment or in reading circles; or it could be a separate activity like a pre/after-reading, pre/after-watching or picture/diagrambased discussion in the classroom.

In order to implement Socratic questioning into the classroom, the teachers had to choose a thought-provoking written or media text on a specific topic or an interesting visual (pictures, graphs, diagrams) and prepare a set of contextual questions to start and guide a discussion. Socratic questions had to be formulated in such a way that they could challenge students to develop their analytical, synthesizing, and evaluating skills.

Based on the formal mechanics of Socratic questioning suggested by Paul and Elder (2006), we used exploratory-type Socratic questions in order to find out what students knew or thought on an issue raised in the text. They were also useful in introducing a subject, preparing students for later analysis of a topic. In exploratory discussions, the teachers used the following types of questions to foster students' analytical abilities: What is 
an ecosystem? Why is survival on land for plant organisms difficult? What is conservation of an ecosystem? How can human practices damage ecosystems? What is the importance of preserving habitat? What are some examples of human practices that can change ecosystems?

Focused-type Socratic questions encouraged students to focus on specific topics and issues, all part of the curriculum. The teachers used them to guide after-reading or after-watching discussions. Focused Socratic questioning helped students clarify, sort, analyze, and evaluate ideas; distinguish facts from opinions; synthesize relevant factors and construct knowledge. For example: What is the relation between agriculture and climate? How would you support your point of view? What do you predict will happen in the relation between agriculture and climate in 100 years time? What evidence supports your hypothesis? Focused Socratic discussion stimulated students to develop multiple viewpoints on the topic. Also, it gave students experience in engaging in an extended dialogue in which they discover, develop, and share ideas.

3. Group presentations. As a teaching method, group presentations are very beneficial in relation to the development of critical thinking skills together with mastering English proficiency. Group presentations incorporate the four main principles making meaning, active learning, cooperation and using thinking organizers - into thinking-based language learning. While making group presentations, students practiced language skills as well as critical thinking and social skills.

During the semester, students divided themselves into groups of three to prepare for a presentation to deliver upon the completion of each thematic block. In total, each group made two presentations during the semester. Each group needed to use brainstorming to formulate the main idea about the topic, search the Internet for relevant ideas about the topic and assessing the information critically, and arrange the ideas in a creative way. The students required after-class meetings with the teacher for language support before presentations. All the members of the group needed to present ideas in front of the class: some were in charge of the opening part, some of explaining the ideas, some of concluding the ideas and answering questions after the talk. In this way, not only could the teamwork be better assessed, but also the work and contribution of each team member.

Examples of topics for group presentations:

Farming is a profession of hope (Brian Brett)

The nation that destroys its soil destroys itself (Franklin D. Roosevelt)

Agriculture is the most healthful, most useful, and most noble employment of men (George Washington)

The farmer has to be an optimist, or he wouldn't still be a farmer (Will Rogers)

For the French class, this topic was presented:

Vivre en ville - vivre en campagne
Les sports en campagne

Le futur de la planete

Je pense donc je suis (Descartes)

Similarly, as in the classes of English, students of French were supposed to write firstly some ideas according to the typical structure, using some speech acts as follows.

For making an introduction, students used several of these expressions:

Commencez par une phrase d'introduction, par une idee generale, question ou par ue reference qui a un raport au the me. Annoncez le theme. Resumez votre plan de l'expose.

Mesdames et Messieurs, bonjour ! Cher jury, bonjour ! Bonjour !

Phrase d'introduction : Commençons, si vous le voulez bien, par... Je commencerais par la question de la pollution causee par les produits chimiques.

Reflexion: J'aimerais vous demander de reflechir a la situation dans laquelle nous serions aujourd'hui si l'ordinateur n'existait pas.

Question: Combien d'entre vous souhaiteraient passer vos vacances de Noel au Mexique? Le monde moderne se declare insatisfait de la vie urbaine et de ses tensions et critique bien la pollution, l'energie nucleaire, les produits chimiques... . Ces accusations sont-elles vraiment justifiees?

Theme:

Je voudrais aujourdhui vous parler d'une invention qui tarde a prendre son envol : la voiture electrique.

Telle est la question que je voudrais aborder / traiter avec vous maintenant / a laquelle je voudrais essayer de repondre.

Dans cette intention, j'ai choisi un certain nombre d'exemples qui me paraissent particulierement significatifs. En effet, ...

Les idees generales, le plan:

Mon objectif est de vous informer des projets actuellement en cours au Quebec et en France.

Mon objectif est de vous persuader d'adherer au projet d'echange France-Quebec offert dans notre ecole l'an prochain.

Je parlerai tout d'abord / premierement / en premier lieu des...

Je commencerai(s) par aborder les problemes de la pollution et notamment ceux de..

Ensuite / en second lieu/point nous etudierons les problemes de sante et enfin / pour terminer nous dirons quelques mots au sujet des loisirs et $d u$ mode de vie actuel.

Mon expose comprend trois parties :

1- l'historique des services bancaires ;

2- la presentation de deux projets de portefeuille electronique au Quebec et en France ;

3- pour finir, les implications sociales reliees a cette nouvelle technologie. 
Oral group presentation body or written text body:

Developpez les idees, ne vous eloignez pas trop de l'idee principale. Creez des phrases simples et courtes.

Utilisez les verbes activement.

$S i$ vous utilisez les termes, exprimez-vous comprehensiblement. Si vous citez les autres auteurs, soyez exacts.

Depuis 1990... A nie Depuis quelques annees, ...

Dans un article paru dans La Presse du 15 juin 2004, 20\% de la population...

Ne repetez pas les mots. Utilisez les synonymes. Demontrez ainsi votre richesse du vocabulaire.

Si vous argumentez, soyez clair et pertinent. Ainsi vous reussirez a persuader le public. Utilisez les exemples.

Le metro est le moyen de transport de l'avenir ! En effet, il est moins cher en comparaison de la voiture, il reduit la pollution et evite les bouchons.

Utilisez les graphiques, les statistiques, images.

Distinguez les faits des opinions et sentiments. Les entiments ne changent rien.

Fait:

Le mois dernier, des loups ont devore cinq moutons dans divers endroits de notre region.

Opinion:

Les autorites locales pourraient suggerer des mesures a prendre afin d'eloigner ces carnivores des fermes, comme par exemple...

\section{Sentiment:}

Comme tous les membres de ma famille, je crains que les animaux de notre ferme ne soient attaques par...

Accentuez les idees importantes lesquelles vous soutenez. Vous pouvez utiliser d'autres manieres pour les dire.

Conclusion was made up this way:

Concluez les idees dans un bon moment de votre expose. Faites une conclusion interessante, pas trop longue, pas trop courte, pertinente. Pour resumer...

Je vous ai presente aujourd'hui l'evolution des services bancaires automatises - deux projets de portefeuille electronique, l'un au Quebec, l'autre en France - ainsi que l'impact de cette invention sur notre societe.

Le but est que le public retient lidee principale de l'expose.

Si vous ne deviez retenir qu une seule chose de mon expose, ce serait la suivante: si un jour vous vous perdiez en foret, essayez de rester calme...

Comme je l'ai mentionne au debut de mon expose, vous pouvez mettre en application les idees que je vous ai proposees sur...,

Je suis persuade que vous..

Ce que je voudrais dire par la, c'est que...

Je voudrais vous quitter sur cette derniere reflexion...

Avez-vous des questions a me poser?

Quelles questions voulez-vous me poser?

Mon expose est termine et je suis pret(e) a repondre a vos questions.
Je ne suis pas sûr(e), mais je...

Excusez-moi, je me suis trompé(e).

J'ai fait une faute, veuillez excuser mon inexactitude.

Merci de votre attention.

Vous avez ete un public tres attentif et avant de vous quitter, j'aimerais vous offrir cette pensee a mediter :...

Nous remercions notre professeur de nous avoir permis de presenter cet expose. Et nous vous remercions, vous, nos camarades de classe. Vous avez ete un auditoire attentif et vous avez rendu notre tâche tres agreable.

Sme(Some or Slovak sme?) other structures and language functions ere used:

Telle est la question que je voudrais aborder, traiter avec vous maintenant / a laquelle je voudrais essayer de repondre.

Tout d'abord, je parlerai de / premierement / en premier lieu / Disons tout d'abord que / Signalons pour commencer que

Ensuite / En second lieu / point

d'autre part / par ailleurs / notons/signalons a ce propos / a ce sujet / au passage

Pour en revenir a notre propos, je disais donc que ... / Notons d'ailleurs que...

II y a lieu de remarquer a ce propos que / A noter que ...

Cela dit donc...

Voyons donc maintenant / Examinons alors

en general / en bref / dans l'ensemble / en somme

Ce qu'il faut retenir de tout cela c'est que..

Cela montre que / c'est la raison pour laquelle, ...

Enfin / Finalement / Pour terminer / Pour conclure / En conclusion / En guise de conclusion / La conclusion de tout cela est...

Nous pouvons passer maintenant a notre dernier point /Venons-en a notre dernier point

Cela nous amene tout naturellement au dernier point de mon expose

4. Writing assignments. Writing is a very important part of university study. Academic success is impossible without good writing skills. One of the objectives of EFL curriculum is the development of writing skills. A critical thinking approach to writing teaches students how to evaluate gathered information, to distinguish facts from opinions, to organize information logically in a piece of writing, and to express ideas and opinions clearly and directly.

We chose the three basic types of writing used in university courses: an abstract, an essay and a report. In these types of writing the students practice critical thinking skills like developing an argument, comparing and contrasting ideas, making reasoning and sequencing, combining and organizing ideas, summarizing information, drawing conclusions, etc.

During the semester, students were required to write one abstract for an article from a journal, one essay, and one report. In French classes, their curriculum was more exigent; we present 
in this study just a part of their outcomes -an essay on one of the topics already presented.

Now, we shall describe how the teachers organized this type of activity in the EFL classroom.

STEP 1: The teachers instructed students on how to write a particular piece of writing: the structure, useful vocabulary, special language techniques, etc. The students were explained how to gather the information and work with it. Based on thoughtprovoking questions from the teacher, students learned how to evaluate information and information sources, to compare, contrast and combine ideas, and draw conclusions. At this stage, the teachers prepared sample materials: abstracts to articles, essays, and reports, as well as cards with useful vocabulary and worksheets with thinking organizers.

STEP 2: The teachers made out a list of topical questions for each type of writing and supplementary worksheets.

Students had to choose one of the questions from the list for writing. Here, we illustrate a list of questions as examples:

1. What is the scope of agriculture? Why is it important for a human being?

2. What is the difference between traditional and modern agriculture? What evidence supports your hypothesis?

3. Agriculture affects everyone not just farmers. Can this statement be validated?

STEP 3: In the classroom, each student had to be given a task and a worksheet with a thinking organizer to support their thinking process in completing the task.

Students were encouraged to consult the teacher for any language problems when drafting the piece of writing. The finished works were submitted to a teacher the next week after having been revised as homework.

STEP 4: In assessing the written works, teachers focused on the student's critical thinking ability and the construct of meanings. In addition, the students' language progress was also very important. So, two aspects were considered in assessment: thinking and language progress.

Now, we are going to give an example of how we used the two combined teaching strategies (Socratic questions-based discussions and writing assignments) in the thinking-based EFL class followed by a criterion-related assessment of thinking in practice. The topic of the lesson was "The Global Food Security." In order to introduce the topic, the teacher asked several exploratory-type Socratic questions which revealed what students knew or thought about the problem: "What is food security?", "Why is the problem of food security very important nowadays?", "Do you know about the people still suffering from hunger?", "Why do you think there are regions where people are experiencing food insecurity?", etc. These questions motivated students to study statistics and facts further, analyze and evaluate information about the topic. After that, the teacher posed the following challenge: "Imagine you are members of the Food and Agriculture Organization of the UN who are working on different approaches to promote food security worldwide. Identify possible causes of food insecurity in different parts of the world and propose effective solutions to enhance food supply in difficult regions". In the class, the students worked together in collaborative thinking groups and used a specially designed thinking organizer to record their ideas (Appendix 5).

The quality of the work was assessed against the following points:

- several challenges were identified and explained;

- every challenge got a corresponding solution.

Using the Basic Criterion-based Scheme for Assessing CTS (Appendix 1), the teacher evaluated the following thinking skills demonstrated by students during the work: reasoning skills, building new ideas skills, and inference skills. With a Card for Self Assessment (Appendix 3), students identified their strong and weak thinking abilities in performing this task.

Then, the teacher asked the students the following: "Now let's translate our good thinking into good writing". The writing assignment was an essay "Ensuring a growing world population with foodstuffs." The students finished writing the essay as a home assignment. Based on the class discussion, the teacher considered the following points in the essay for evaluation:

- In the introduction, judgments are made about the importance of global food security.

- In the main part, several problems of food insecurity are stated; several modern approaches to the problem are considered.

- In conclusion, the personal opinion about the solution to the problem is expressed.

Here is an example of a student's work:

"Ensuring a Growing World Population with Foodstuffs"

How to provide a growing world population with food? - That is a question, which needs a clear answer as soon as possible. Studying statistics, I found the following figures: these days about 1 billion people - one-seventh of the world population - do not get enough food. They're predominantly from Africa and Asia. It is expected that in the nearest 40 years the number of the world population will increase to 10 billion. That means that humanity will need twice as much food than it is now.

One can think that everything would be fine if you first plow, then plant, pick and eat. But in this case, it's not so simple: the last fifty years crops planting doubles and the amount of arable land area only decreases. In addition, people are tired of vegetarian food - human wants eating meat. And if you want meat, you need to feed and grow it. These trends only increase the need for arable land and agriculture.

There are many modern approaches to people's provision of food. For example, the expansion of aquaculture (when fish and shellifish are cultivated) seems to be an interesting idea. Also, agronomists try to solve the problems of desertification and land erosion for better yield. On the other hand, geneticists try to deduce the gene in plants tolerance to draining. 
Table 1 Description of skills

\begin{tabular}{|c|c|c|c|c|}
\hline & $\begin{array}{l}\text { Standard } \\
\text { Criteria }\end{array}$ & $\begin{array}{l}\text { Unacceptable level } \\
\text { (1-2 marks) }\end{array}$ & $\begin{array}{l}\text { Limited level } \\
\text { (3 marks) }\end{array}$ & $\begin{array}{l}\text { Acceptable level } \\
\text { (4-5 marks) }\end{array}$ \\
\hline $\begin{array}{l}\text { Analytical } \\
\text { skills }\end{array}$ & reasoning skills & & & \\
\hline \multirow[t]{2}{*}{$\begin{array}{c}\text { Synthesizing } \\
\text { skills }\end{array}$} & $\begin{array}{l}\text { building new ideas } \\
\text { skills }\end{array}$ & & $\begin{array}{l}\text { Presents ideas } \\
\text { sporadically without } \\
\text { establishing } \\
\text { a clear relationship } \\
\text { between them. }\end{array}$ & $\begin{array}{l}\text { Considers the problem } \\
\text { from different perspectives } \\
(\text { GMP) in the Main Part. } \\
\text { Uses appropriate language. }\end{array}$ \\
\hline & $\begin{array}{l}\text { thinking "outside the } \\
\text { box" skills }\end{array}$ & & & $\begin{array}{l}\text { Finds } 3 \text { ways to deal } \\
\text { with the problem. } \\
\text { Able to think differently about the situation (GMP) } \\
\text { in the Main Part. Uses appropriate language. }\end{array}$ \\
\hline \multirow[b]{2}{*}{$\begin{array}{l}\text { Evaluation } \\
\text { skills }\end{array}$} & $\begin{array}{c}\text { assessing information } \\
\text { skills }\end{array}$ & & & $\begin{array}{c}\text { Distinguishes facts from opinions. Determines } \\
\text { biases (GMP) } \\
\text { in the Main Part. Uses } \\
\text { appropriate language. }\end{array}$ \\
\hline & 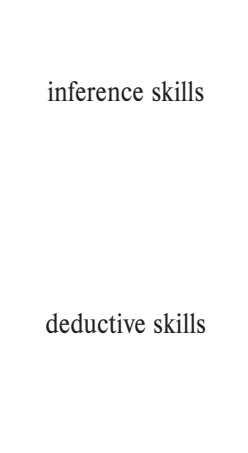 & & & $\begin{array}{c}\text { Formulates own opinions based } \\
\text { on information they have } \\
\text { learned in Conclusion. } \\
\text { Uses appropriate language. } \\
\text { Draws the conclusion } \\
\text { by considering the information } \\
\text { or evidence they have } \\
\text { in Introduction and } \\
\text { in Conclusion. Uses } \\
\text { appropriate language. }\end{array}$ \\
\hline
\end{tabular}

As for genetics and its product - genetically modified foods - I can say that the abbreviation "GMP" seems to frighten an average inhabitant of the planet. And it may be really so because scientists haven't discovered the long-term consequences of the influence of such products on animals and people yet. But we must remember that GMPs are not just the chemicals introduced by man in a white robe in ripe fruit, and much less fruit and vegetables are grown in greenhouses on artificial branches. Any selection result is already a genetically modified product. I'm sure this information must make you confident in genetics. This scientific trend is still young (about 40 years), but scientists are constantly making observations and conducting researches and, therefore, safe methods are found.
In our opinion, the man will be saved! However, if he really wants to. These days a third of the world population lives in overabundance. And the rational distribution of resources could solve the problem of food provision. Although, there is already a useless dry scientific statement: go and take a piece of bread and feed the hungry."

In the written work whether in English or in French, the students were expected to manifest the following thinking skills: reasoning skills, building and combining ideas skills, thinking "outside the box" skills (Table 1), assessing information skills, inference skills, and deductive skills that were assessed by the teacher using the scheme from Appendix 1. 


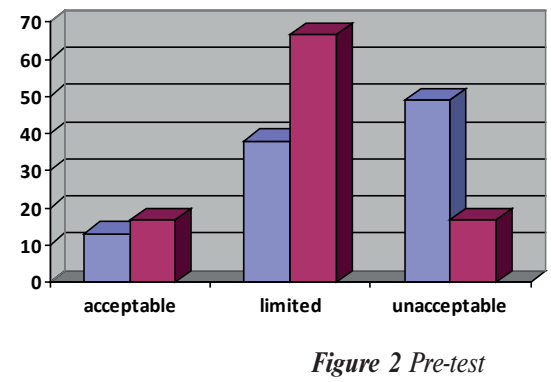

\section{Results}

At the start and the end of the thinking-based EFL course, the students took the Cambridge Thinking Skills Assessment Test (CTSA) translated into Russian (Figure 2) to avoid any confusion in meanings that may incur due to language problems. The results of the pretest showed different results which are not on a comparable level. The reason for this is that there were only 12 French speaking-students as opposed to 75 English-speaking students. The results showed that only $13.33 \%$ of students had an acceptable level of critical thinking skills, $37.33 \%$ of students revealed a limited level and $49.33 \%$ - an unacceptable level.

As for the French-speaking students in Nitra University, the CTA (Evaluation des capacités d'analyse et de la pensée critique), online test, was used. The French-speaking students were doing the pre-test in the middle of the semester when the course was already running. Despite that, it showed that $16.66 \%$ of students reached an acceptable level of critical thinking, $66.66 \%$ a limited level, and $16.66 \%$ an acceptable level.

The posttest (Figure 3) results were more optimistic with the increased number of students who had made a significant improvement in critical thinking abilities: $39.33 \%$ of students had an acceptable level; $36.33 \%$ - a limited level, and $24.33 \%$ - an unacceptable level.

The posttest results for French-speaking students: $41.66 \%$. acceptable level, 58.33\% limited level and $0 \%$ unacceptable level. A big improvement was made.

\section{Discussion}

The study produced several findings. First, the number of students who scored low on the CTSA (for French CTA) pretest grew half as much - their overall critical thinking skills had made an improvement by the end of the course. Especially, those who demonstrated a limited level at the start made a significant improvement. In the posttest, they had a high score, which showed their critical thinking progress. Thus, by the end of the course, the prevailing number of students within each group had an acceptable or a limited level of critical thinking skills.

Second, the results of the language end-term exam showed better academic achievements of the students with a medium

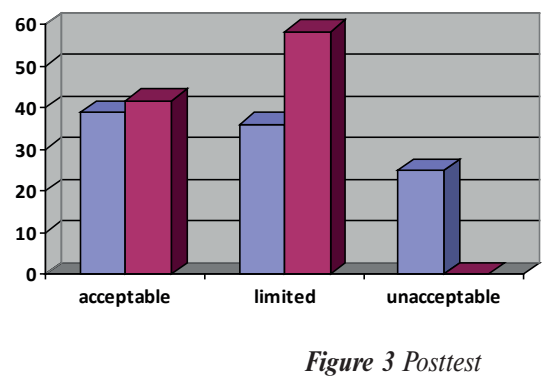

$\square$ Russian students - Slovak students

and high critical thinking score. Therefore, students' language proficiency was related to the acquisition of their critical thinking skills.

Third, in the final discussion at the end of the term, regardless of their language proficiency the students mentioned that they had been more interested and motivated in learning during the second term. They felt more confident in challenging the answers and sharing thoughts.

Another finding is that the students became more self-reliant with critical thinking and they understood the importance of developing critical thinking skills. When the students responded to the question "What have you learned from this course?" they said that "developing critical thinking would be useful to my future career or further study"; "it is important to apply critical thinking in different areas of study"; "I became more confident in asking and answering "why" and "how."

With a built up confidence, students communicate more effectively.

Finally, answering the questionnaire (Appendix 5), the students highly agreed they benefited the most from Socraticquestions-based discussions in developing critical thinking. When responding to the questions "What is the activity that helped me the most in learning?" and "What is the activity that helped me develop critical thinking the most?" most of the students chose "Socratic-questions-based discussions." Besides, students highly agreed that "In-class Socratic-questions discussion helped me understand the reading or writing assignment better," and "In-class Socratic-questions discussion helped me see different aspects of the same problem."

However, as to the self-directed learning activities - "group presentations" and "writing assignments" - the students responded: "Group presentations helped me improve in cooperative learning" and "Writing an essay helped me cultivate analytically and evaluating thinking skills." According to students, "Reading circles helped me focus on different details in the text and comprehend the text better"; "helped me improve my communication skills."

The main objective of the study was to identify the most effective suitable techniques for developing critical thinking skills in students in EFL and/or FFL classes. The findings in this study support that the "reading circles"; Socratic-questionsbased discussions; group presentations; and writing assignments help the weak thinkers improve their overall critical thinking and 


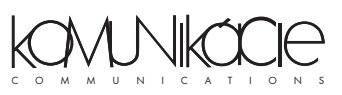

especially demonstrate better skills in analysis and evaluation. The teachers' in-class observation and students' responses to the questionnaire testified that the latter felt more comfortable and assertive in the guided in-class activities like "reading circles" and Socratic-questions-based discussions. Most of the students noted that thinking organizers and teamwork helped them a lot to develop critical thinking in an enjoyable learning environment.

As to the question of correlation between strong critical thinking abilities and academic performance, the findings showed that students' English proficiency relates to their acquisition of critical thinking skills. The findings revealed that weak thinkers with low or relatively low English proficiency at the beginning of the second term succeeded both in critical thinking and English performance by the end of the term.

\section{Conclusion}

The study has discussed the efficacy of particular teaching techniques and strategies for developing communication, writing skills and critical thinking skills in undergraduate students in EFL and FFL class. In general, the findings supported the methodology of this course and provided some insight into the research questions. It is found out that if students are equipped with critical thinking skills, they could be more self-confident and confident in adapting to a new situation or even more successful in their future profession or advanced study.

This study also found a few implications for thinking-based teaching techniques. First, EFL and FFL University teachers should infuse specific thinking skills into content instruction, followed by regular and varied practice in both guided and selfdirected activities at the start of the first term in order to develop the habit of critical thinking through a longer-term practice. Second, students need to be explained the importance of group presentations. Group presentation does not merely help cultivate their critical thinking but also helps build communication skills and enhance their teamwork skills and employability. EFL and FFL teachers should elaborate more on explicit thinking instructions or thinking organizers for students that will guide the student preparation process. Third, teachers should provide opportunities for students to use their critical thinking skills in connection with other types of activities such as research work, project work, etc.

\section{References}

[1] BRAUN, N. M.: Critical Thinking in the Business Curriculum. Journal of Education for Business, 79, 232-236, 2004.

[2] HALPERN, D.: Teaching Critical Thinking for Transfer across Domains: Dispositions, Skills, Structure Training, and Metacognitive Monitoring. American Psychologist, 53, 449-455, 1998.

[3] KLACZYNSKI, P. A.: Framing Effects on Adolescent Task Representations, Analytic and Heuristic Processing, and Decision Making: Implications for the Normative/descriptive Gap. Journal of Applied Developmental Psychology, 22, 289-309, 2001.

[4] FACIONE, P. A., SANCHEZ, C. A., FACIONE, N. C., GAINEN, J.: The Disposition of Critical Thinking. Journal of General Education, 44(1), 1-25, 1995. For a recent study on the impact of mass media on the immerging adults in the Slovak consumerist society see: LESKOVA, A., VALCO, M.: Identity of Adolescents and its Dimensions in the Relation to Mass Media: PhilosophicalEthical Reflections. In: XLinguae, 10(3), 324-332, 2017. An innovative analysis of what might be called "relational anthropology" as an answer to this challenge offer Valco and Sturak in VALCO, M., STURAK, P.: The 'Relational Self': Philosophical-Religious Reflections in Anthropology and Personalism. XLinguae, 11(1XL), 289-299, 2018.

[5] DOlZhiKOVA, A., KURILENKO, V., BIRYUKOVA, Y., RUMYANTSEVA, N., MAKAROVA, M., KULIKOVA, E.: Specific Features of Special Discourse Genres in Information Technology. XLinguae, 10(3), 3-14, 2017. DOI: 10.18355/XL.2017.10.03.01

[6] KARAMALAK, O., PESINA, S.: Linguistic Sign and Reading as Text Creating Activity. XLinguae, 10(1), 2-11, 2017. DOI: 10.18355/XL.2017.10.01.01

[7] FENCLOVA, M., HOROVA, H.: The Expression of Politeness and Modesty in the Texts of the Social Sciences/La politesse et la modestie dans des textes de sciences humaines (in French). XLinguae, 10(1), 42-48, 2017. DOI: 10.18355/XL.2017.10.01.05

[8] KLIMOVA, K.: Writing Research Article Introduction in Italian. XLinguae, 10(1), 49-61, 2017. DOI: 10.18355/XL.2017.10.01.06

[9] AHMADI, A., MEIHAMI, H.: The Development of Complexity, Accuracy, and Fluency in ESP Learners' Writing: A Dynamic Systems Theory. XLinguae, 10(3), 57-74, 2017. DOI: 10.18355/XL.2017.10.03.05

[10] TAREVA, E. G., SCHEPILOVA, A. V., TAREV, B. V.: Intercultural Content of a Foreign Language Textbooks: Concept, Texts, Practices. XLinguae, 10(3), 246-255, 2017. DOI: 10.18355/XL.2017.10.03.20

[11] PAlaSheVSKayA, I. V., LEONTIEV, V. V., KURCHENKOVA, E. A., STEPANOVA, E. D., BULANOV, D. S.: Correlations of Status Positions of Courtroom Discourse Participants. XLinguae, 10(3), 45-56, 2017. DOI: 10.18355/XL.2017.10.03.04 
[12] KRAlOVA, Z., PETROVA, G.: Causes and Consequences of Foreign Language Anxiety. XLinguae, 10(3), 110-122, 2017. DOI: 10.18355/XL.2017.10.03.09

[13] LAH, M.: Raising Awareness in University Students of Languages/La conscientisation des apprenants de langue au niveau universitaire (in French). XLinguae, 10(4), 320-334, 2017. DOI: 10.18355/XL.2017.10.04.26

[14] BIROVA, J.: Comparison of Study Conditions for Final Examination from French - A Longitudinal Study/Porovnanie podmienok pripravy studenta na maturitnu skusku z francuzskeho jazyka - longitudinalna studia (in Slovak). Slavonic Pedagogical Studies Journal, 6(2), 288-313, 2017. DOI: 10.18355/PG.2017.6.2.9

[15] ENNIS, R. H.: A Concept of Critical Thinking. Harvard Educational Review, 32(1), 81-111, 1962.

[16] ENNIS, R. H.: A Taxonomy of Critical Thinking Dispositions and Abilities. BARON, J., STERNBERG, R. (Eds.): Teaching Thinking Skills: Theory and Practice. WH Freeman/Times Books/Henry Holt \& Co, New York, p. 9-26, 1987.

[17] MCGUINNESS, C.: Teaching Thinking: Theory and Practice. British Journal of Educational Psychology, Monograph Series II, 3, 107-127, 2005.

[18] BLOOM, B., ENGLEHART, M, FURST, E., HILL, W., KRAHTWOHL, D.: Taxonomy of Educational Objectives: The Classification of Educational Goals. Handbook 1: Cognitive Domain. Longmans Green, New York, 1956.

[19] SWARTZ, R. J., COSTA, A., KALLICK, B., BEYER, B., \& REAGAN, R.: Thinking-Based Learning: Activating Students' Potential. Christopher-Gordon Publishers, Norwood, MA, 2007.

[20] SWARTZ, R.J., PARKS, D.: Infusing the Teaching of Critical and Creative Thinking in Elementary Instruction. Critical Thinking Books \& Software, Pacific Grove, CA, 1994.

[21] BROWN, H.: Teaching by Principles. Addison Wesley Longman, White Plains, NY, 2001.

[22] BONWELL, C., EISON, J.: Active Learning: Creating Excitement in the Classroom. Information Analyses. ERIC Clearinghouse Products (071), 1991.

[23] GILLES, R.M., ADRIAN, F.: Cooperative Learning: The Social and Intellectual Outcomes of Learning in Groups. Farmer Press, London, 2003.

[24] BURNS, B.: Changing the Classroom Climate with Literature Circles. Journal of Adolescent \& Adult Literacy, 42, 124-129, 1998.

[25] CUMMIN-POTWIN, W.: Scaffolding, Multiliteracies, and Reading Circles. Canadian Journal of Education, 30(2), 483-507, 2007.

[26] HEBERT, H.: Literary Circles and Reading Review as Intervention Elements in Methodlogy of Teaching Literature: A Case Study of a Pupil with Special Needs/Cercles litteraires et journal de lecture comme elements d'intervention en didactique de la litterature: etude de cas d'un eleve de $8^{\mathrm{e}}$ annee en difficulte (in French). Revue du Nouvel-Ontario, 34, 83-117, 2009.

[27] PAUL, R., ELDER, L.: The Art of Socratic Questioning. Dillon Beach, CA: Foundation for Critical Thinking. Psychology, Monograph Series II, 3, 107-127, 2006.

[28] SWARTZ, R.: Towards Developing and Implementing a Thinking Curriculum. First Annual Thinking Qualities Initiative Conference, Hong Kong, 2000.

[29] MESKOVA, L.: Translation of Vulgarism in Mass Media. XLinguae, 10(3), 101-109, 2017. DOI: 10.18355/XL.2017.10.03.08

[30] DROVOSEKOV, S. E., SAKHIEVA, R. G.: Peculiarities of Using Projects in Learning English as a Foreign Language. XLinguae, 11(1), 91-102, 2018. DOI: 10.18355/XL.2018.11.01.09

[31] LEBEDEVA, O., BYKOVA, S., MASAliMOVA, A. R., SOKOLOVA, N. L., KRYUKOVA, N. I.: Peculiarities of Developing High School Students' Lexical Skills by Means of the Programmed Learning Technology. XLinguae, 11(1), 186-202, 2018.

[32] JOHNSON, D.W.: An Educational Psychology Success Story: Social Interdependence Theory and Cooperative Learning. Educational Researcher, 38(5), 365-379, 2009.

[33] DEBONO, E.: The Use of Lateral Thinking, 2nd edition. Jonathan Cape, London, 1990.

[34] SHARMA P.: A Study of Learning-Thinking Style of Secondary School Students in Relation to their Academic Achievement. International Journal on New Trends in Education and Their Implications, 2(4), 115-23, 2011.

[35] NASRABADI, B.H., MOUSAVI, K., FARSAN ZABIHULLAH, S.: Attitude of Critical Thinking and Cognitive Learning Styles in Predicting Academic Achievement of University Students. Iranian Journal of Medical Education, XII(4), 285-296, 2012.

[36] ANDERSON, P., CORBETT, L.: Literature Circles for Students with Learning Disabilities. Intervention in School and Clinic, 44(1), 25-33, 2008. 


\section{Appendix 1}

Basic Criterion-Based Scheme for Assessing CTS

\begin{tabular}{|c|c|c|c|c|}
\hline & $\begin{array}{l}\text { Standard } \\
\text { Criteria }\end{array}$ & $\begin{array}{l}\text { Unacceptable level } \\
\text { (1-2 marks) }\end{array}$ & $\begin{array}{l}\text { Limited level } \\
\text { (3 marks) }\end{array}$ & $\begin{array}{l}\text { Acceptable level } \\
(4-5 \text { marks })\end{array}$ \\
\hline \multirow{3}{*}{$\begin{array}{l}\text { Analytical } \\
\text { skills }\end{array}$} & $\begin{array}{l}\text { comparing and } \\
\text { contrasting skills }\end{array}$ & $\begin{array}{l}\text { Does not explicitly identify } \\
\text { similarities and differences between } \\
\text { or among objects, ideas, concepts, } \\
\text { events, or other subjects. Lacks } \\
\text { knowledge of the items being } \\
\text { compared and contrasted. } \\
\text { Does not use thinking language. }\end{array}$ & $\begin{array}{l}\text { Finds out } 1-2 \text { similarities } \\
\text { and differences between } \\
\text { or among objects, ideas, } \\
\text { concepts, events, or other } \\
\text { subjects. } \\
\text { Demonstrates little } \\
\text { knowledge of the items being } \\
\text { compared and contrasted. } \\
\text { Does not use appropriate } \\
\text { language. }\end{array}$ & $\begin{array}{l}\text { Finds out 3-4 similarities and } \\
\text { differences between or among } \\
\text { objects, ideas, concepts, events, } \\
\text { or other subjects. Demonstrates } \\
\text { knowledge and understanding of } \\
\text { the items being compared and } \\
\text { contrasted. } \\
\text { Uses appropriate language. }\end{array}$ \\
\hline & classifying skills & $\begin{array}{l}\text { Does not define a group of objects. } \\
\text { Does not use thinking language. }\end{array}$ & $\begin{array}{l}\text { Has difficulty in identifying } \\
\text { common attributes of objects } \\
\text { and defining a group of } \\
\text { them. } \\
\text { Does not use appropriate } \\
\text { language. }\end{array}$ & $\begin{array}{l}\text { Identifies, compares and contrasts } \\
\text { characteristics to define a group } \\
\text { of objects. Communicates the } \\
\text { basic characteristics (attributes) } \\
\text { of the groups, using appropriate } \\
\text { language. }\end{array}$ \\
\hline & reasoning skills & $\begin{array}{l}\text { Does not recognize that there is } \\
\text { a problem, it needs to be pointed } \\
\text { out. } \\
\text { Does not collect relevant facts or } \\
\text { arguments. } \\
\text { Does not give a way to deal with } \\
\text { a situation or solve a problem. } \\
\text { Does not come up with any } \\
\text { solutions for a problem. } \\
\text { Does not use thinking language. }\end{array}$ & $\begin{array}{l}\text { Recognizes there could be } \\
\text { a problem. } \\
\text { Collects relevant and } \\
\text { irrelevant facts or } \\
\text { arguments. Considers one } \\
\text { way to deal with a situation } \\
\text { or solve a problem. Identifies } \\
\text { one solution. Does not use } \\
\text { appropriate language. }\end{array}$ & $\begin{array}{l}\text { Identifies the problem, relevant } \\
\text { facts or arguments, rejecting useless } \\
\text { information. Considers different } \\
\text { ways to deal with a situation or } \\
\text { solve a problem. Identifies potential } \\
\text { solutions and decides on the best } \\
\text { one. } \\
\text { Uses appropriate language. }\end{array}$ \\
\hline \multirow{4}{*}{$\begin{array}{l}\text { Synthesizing } \\
\text { skills }\end{array}$} & $\begin{array}{l}\text { building new ideas } \\
\text { skills }\end{array}$ & $\begin{array}{l}\text { Considers a situation from one } \\
\text { point of view. Discounts others' } \\
\text { perspectives and points of view. } \\
\text { Not able to generate new ideas. } \\
\text { Does not use thinking language. }\end{array}$ & $\begin{array}{l}\text { Considers a situation from } \\
\text { one or two perspectives. Has } \\
\text { difficulty in building new } \\
\text { ideas. } \\
\text { Does not use appropriate } \\
\text { language. }\end{array}$ & $\begin{array}{l}\text { Able to consider a situation from } \\
\text { different perspectives and generate } \\
\text { new ideas. } \\
\text { Uses appropriate language. }\end{array}$ \\
\hline & $\begin{array}{l}\text { combining ideas } \\
\text { skills }\end{array}$ & $\begin{array}{l}\text { Does not combine ideas. } \\
\text { Does not use thinking language. }\end{array}$ & $\begin{array}{l}\text { Combines ideas sporadically } \\
\text { without establishing } \\
\text { relationships among them. } \\
\text { Does not use appropriate } \\
\text { language. }\end{array}$ & $\begin{array}{l}\text { Establishes the relationship } \\
\text { between/among ideas in order to } \\
\text { combine them. Uses appropriate } \\
\text { language. }\end{array}$ \\
\hline & $\begin{array}{l}\text { thinking "outside the } \\
\text { box" skills }\end{array}$ & $\begin{array}{l}\text { Does not find ways to deal with the } \\
\text { problem/situation. }\end{array}$ & $\begin{array}{l}\text { Finds a usual way to deal } \\
\text { with the problem/situation. }\end{array}$ & $\begin{array}{l}\text { Finds } 3-4 \text { new ways to deal with the } \\
\text { problem/situation. }\end{array}$ \\
\hline & & Does not use thinking language. & $\begin{array}{l}\text { Does not use appropriate } \\
\text { language. }\end{array}$ & $\begin{array}{l}\text { Able to think differently about } \\
\text { the situation. Uses appropriate } \\
\text { language. }\end{array}$ \\
\hline
\end{tabular}




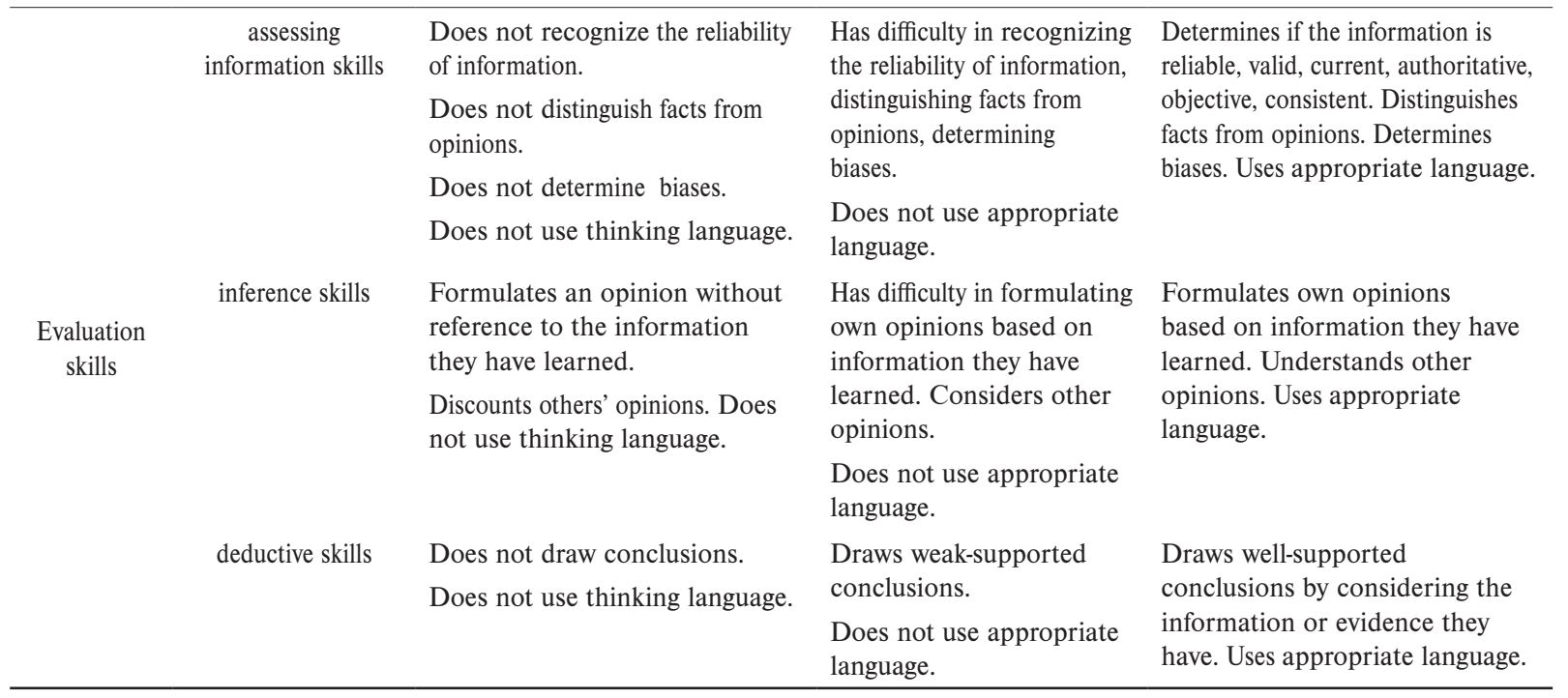

\section{Appendix 2}

\section{A Card for Peer-Assessment of CTS}

Which of the skills were demonstrated by a group member?

\begin{tabular}{lll}
\hline & \multicolumn{1}{c}{ Specific thinking skills } & Put a tick \\
\hline Analytical skills & sequencing skills \\
& classifying skills \\
& ranking skills \\
& comparing and contrasting skills \\
& reasoning skills \\
& \\
Synthesizing skills & building new ideas skills \\
& combining ideas skills \\
& thinking "outside the box" skills \\
& \\
Evaluation skills & recognizing reliability of evidence skills \\
& distinguishing facts from opinion skills \\
& determining biases skills \\
& formulating own points of view skills \\
& seeing other points of view skills \\
drawing conclusions skills
\end{tabular}




\section{kOMNIKoCle}

Appendix 3

\section{A Card for Self-Assessment of CTS}

Which of the thinking can you do?

\begin{tabular}{|c|c|c|c|c|}
\hline & Thinking you can do & $\begin{array}{l}\text { I strongly } \\
\text { agree or it's very } \\
\text { like me }\end{array}$ & $\begin{array}{l}\text { I partly agree } \\
\text { or it's a bit like } \\
\text { me }\end{array}$ & $\begin{array}{c}\text { I disagree or it's } \\
\text { not like me }\end{array}$ \\
\hline $\begin{array}{l}\text { Analytical } \\
\text { skills }\end{array}$ & $\begin{array}{l}\text { I can classify ideas. } \\
\text { I can sequence ideas. } \\
\text { I can rank ideas. } \\
\text { I can compare and contrast ideas. } \\
\text { I can identify the problem and find a solution to it. }\end{array}$ & & & \\
\hline $\begin{array}{l}\text { Synthesizing } \\
\text { skills }\end{array}$ & $\begin{array}{l}\text { I can generate new ideas. } \\
\text { I can combine ideas. } \\
\text { I can think "outside the box". }\end{array}$ & & & \\
\hline $\begin{array}{l}\text { Evaluation } \\
\text { skills }\end{array}$ & $\begin{array}{l}\text { I can recognize reliability of evidence and sources of } \\
\text { information. } \\
\text { I can distinguish facts from opinions. } \\
\text { I can determine biases. } \\
\text { I can formulate my own point of view. } \\
\text { I can see other points of view. } \\
\text { I can draw conclusions. }\end{array}$ & & & \\
\hline
\end{tabular}




\section{Appendix 4}

\section{Satisfaction Questionnaire}

1. Which activity helped you the most in learning? Give each activity the score (1-10) to indicate your level of satisfaction ( 1 - the least satisfied...10 - the most satisfied)
a. Reading circles
b. Socratic-questions discussion
c. Group presentation
d. Writing assignment

2. Which activity helped you develop critical thinking the most? Give each activity the score (1-10) to indicate your level of satisfaction ( 1 - the least satisfied...10 - the most satisfied)

a. Reading circles

b. Socratic-questions discussion

c. Group presentation

d. Writing assignment

3. Complete the sentences:

a. Reading circles helped me

b. Socratic-questions discussion helped me

c. Group presentation helped me

d. Writing assignment helped me

4. What difficulties did you have in each activity?

a. Reading circles:

b. Socratic-questions discussion:

c. Group presentation:

d. Writing assignment: 


\section{kOMNIkCOCle}

Appendix 5

Food Security Promotion

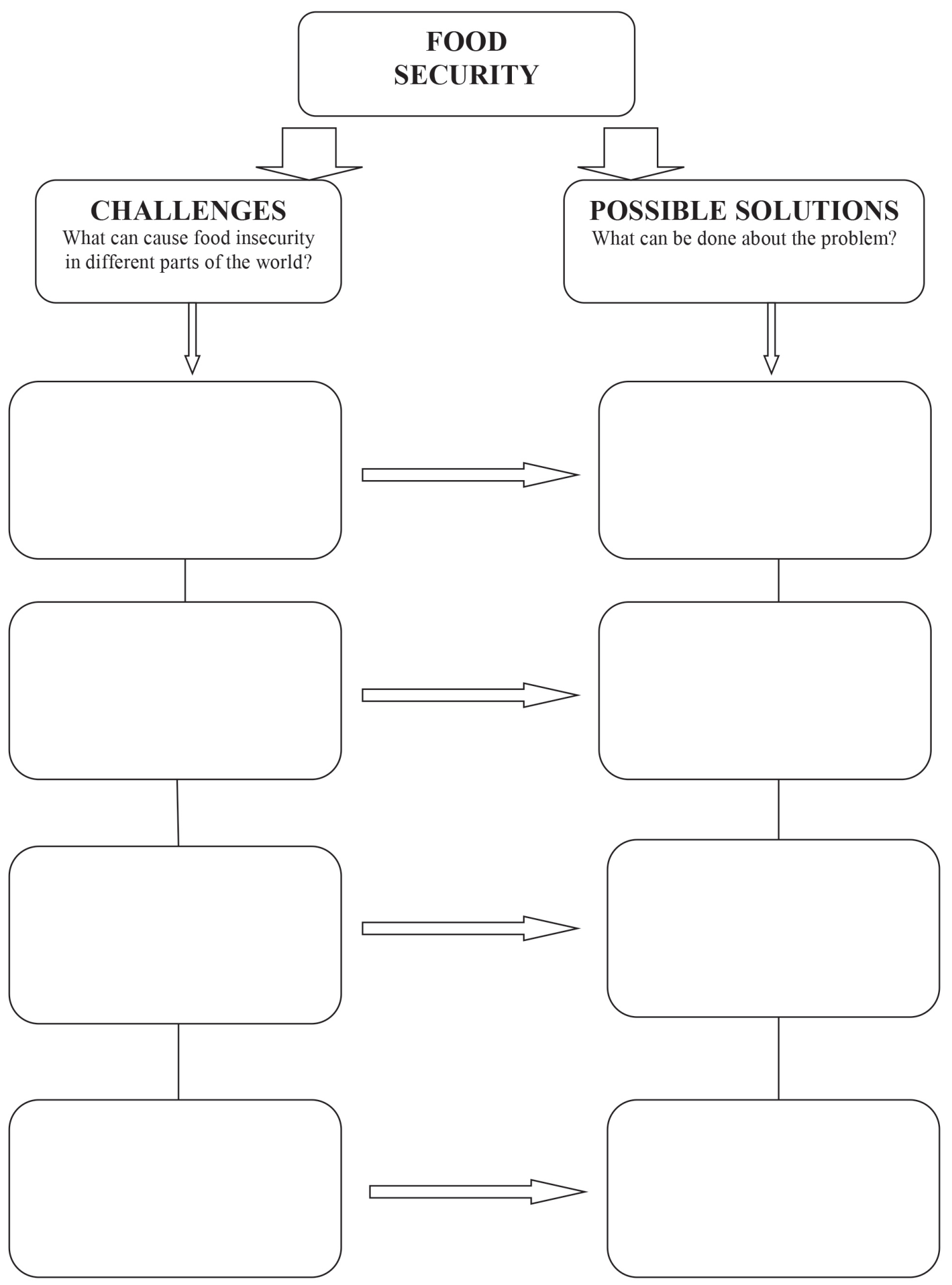

